Published in final edited form as:

Brain Res. 2016 October 1; 1648(Pt A): 434-437. doi:10.1016/j.brainres.2016.08.017.

\title{
Hyperbaric oxygen treatment suppresses withdrawal signs in morphine-dependent mice
}

\author{
Daniel Nicoara ${ }^{\mathrm{a}, 1}$, Yangmiao Zhang ${ }^{\mathrm{b}, 2}$, Jordan T. Nelson ${ }^{\mathrm{a}, 3}$, Abigail L. Brewer ${ }^{\mathrm{a}}$, Prianka \\ Maharaj $^{b}$, Shea N. DeWalda ${ }^{a}$, Donald Y. Shirachi ${ }^{d}$, and Raymond M. Quock ${ }^{a}, b, c,{ }^{*}$ \\ aDepartment of Psychology, Washington State University, Pullman, WA, USA \\ ${ }^{b}$ Department of Integrative Physiology and Neuroscience, Washington State University, Pullman, \\ WA, USA \\ 'Translational Addiction Research Center, Washington State University, Pullman, WA, USA \\ dDepartment of Physiology and Pharmacology, University of the Pacific Thomas J. Long School of \\ Pharmacy and Health Sciences, Stockton, CA, USA
}

\begin{abstract}
Hyperbaric oxygen $\left(\mathrm{HBO}_{2}\right)$ therapy reportedly reduces opiate withdrawal in human subjects. The purpose of this research was to determine whether $\mathrm{HBO}_{2}$ treatment could suppress physical signs of withdrawal in opiate-dependent mice. Male NIH Swiss mice were injected s.c. with morphine sulfate twice a day for 4 days, the daily dose gradually increasing from $50 \mathrm{mg} / \mathrm{kg}$ on day 1 to 125 $\mathrm{mg} / \mathrm{kg}$ on day 4 . On day 5 , withdrawal was precipitated by i.p. injection of $5.0 \mathrm{mg} / \mathrm{kg}$ naloxone. Mice were observed for physical withdrawal signs, including jumping, forepaw tremor, wet-dog shakes, rearing and defecation for $30 \mathrm{~min}$. Sixty min prior to the naloxone injection, different groups of mice received either a 30-min or 60-min $\mathrm{HBO}_{2}$ treatment at 3.5 atmospheres absolute. $\mathrm{HBO}_{2}$ treatment significantly reduced naloxone-precipitated jumping, forepaw tremor, wet-dog shakes, rearing and defecation. Based on these experimental findings, we concluded that treatment with $\mathrm{HBO}_{2}$ can suppress physical signs of withdrawal syndrome in morphine-dependent mice.
\end{abstract}

\section{Keywords}

Hyperbaric oxygen; morphine; opiate withdrawal; physical dependence; mouse

\footnotetext{
"Correspondence author at: Department of Psychology, Washington State University, P.O. Box 644820, Pullman, WA 99164, USA. Fax: + 1509335 5043. quockr@wsu.edu (R.M. Quock).

${ }_{1}^{1}$ Present address: College of Osteopathic Medicine, Pacific Northwest University of Health Sciences, 200 University Parkway, Yakima, WA, USA

2Present address: Department of Neurological Surgery, Oregon Health \& Science University, 3181 S.W. Sam Jackson Park Road, Portland, OR, USA

${ }^{3}$ Present address: College of Pharmacy, Washington State University, P.O. Box 1495, Spokane, WA, USA

Publisher's Disclaimer: This is a PDF file of an unedited manuscript that has been accepted for publication. As a service to our customers we are providing this early version of the manuscript. The manuscript will undergo copyediting, typesetting, and review of the resulting proof before it is published in its final citable form. Please note that during the production process errors may be discovered which could affect the content, and all legal disclaimers that apply to the journal pertain.
} 


\section{Introduction}

Hyperbaric oxygen $\left(\mathrm{HBO}_{2}\right)$ is the clinical application of $100 \%$ oxygen under higher-thannormal atmospheric pressure to achieve therapeutic outcomes. On the recommendation of the Hyperbaric Oxygen Therapy Committee of the Undersea and Hyperbaric Medical Society, $\mathrm{HBO}_{2}$ therapy is approved by the U.S. Food and Drug Administration (FDA) for 14 clinical conditions [Weaver, 2014] but currently not for treatment of opiate addiction. According to a published report, $\mathrm{HBO}_{2}$ was beneficial in patients with narcomania (narcotic addiction) in the post-intoxication and abstinence periods [Epifanova, 1995]. However, this study remains unconfirmed.

Previously, we reported that $\mathrm{HBO}_{2}$ produced an antinociceptive effect in mice that was dependent on both nitric oxide (NO) and opioid receptors [Zelinski et al., 2009]. Further studies suggested that $\mathrm{HBO}_{2}$ might be capable of stimulating neuronal release of endogenous opioid peptides [Heeman et al., 2013]. The purpose of the present investigation was to determine in an animal model whether $\mathrm{HBO}_{2}$ might be capable of reducing the morphine withdrawal syndrome.

\section{Results}

The intraclass correlation coefficients (ICCs) for two independent raters assessing the impact of $\mathrm{HBO}_{2}$ treatment on physical withdrawal signs were as follow: jumps $(a=0.995, \mathrm{P}=$ $0.000)$; rears $(\alpha=0.878, P=0.000)$; and fecal boli $(\alpha=0.826, P=0.000)$. ICCs were not determined for tremors or wet-dog shakes because they were scored in real time by a single rater.

Morphine-dependent mice exhibited averages of $24.6 \pm 8.5$ jumps, $15.6 \pm 2.4$ tremors, 2.9 \pm 0.7 wet-dog shakes, $92.2 \pm 6.8$ rears, and $6.3 \pm 0.8$ fecal boli during a 30 -min observation period following administration of naloxone. After both 30- and 60-min $\mathrm{HBO}_{2}$ treatments, there were statistically significant decreases in all five endpoints: jumps [Welch's $\mathrm{F}(2$, 15.737) $=4.510 \mathrm{P}=0.028$ ]; tremors [Welch's $\mathrm{F}(2,26.911)=6.815, \mathrm{P}=0.004]$; wet-dog shakes [Welch's $\mathrm{F}(2,26.586)=5.790, \mathrm{P}=0.008]$; rears $[\mathrm{F}(2,27)=5.384, \mathrm{P}=0.011]$; and fecal boli $[$ Welch's $F(2,17.719)=8.963, \mathrm{P}=0.002]($ Figs. 2-6) .

\section{Discussion}

We found that naloxone precipitated five cardinal signs of opiate withdrawal—jumping, forepaw tremor, wet-dog shakes, rearing, and defecation [Gabra et al., 2008; Seyedi et al., 2014; Wu et al., 2014] — in morphine-dependent mice. The frequency of all five withdrawal signs was reduced by $\mathrm{HBO}_{2}$ treatment, although the reduction in only four endpoints was statistically significant.

The implications of this research are of profound importance. Current therapies used to treat heroin addiction largely employ opiate medications, including agonists, partial agonists and antagonists. While these drugs can provide relief from the opiate withdrawal syndrome, they are still prone to development of physical dependence and risk of relapse [Kleber, 2007]. 
Although one isolated study reported that $\mathrm{HBO}_{2}$ alleviated opiate withdrawal in humans [Epifanova, 1995], the present study is, to our knowledge, the first to demonstrate this phenomenon in an animal model of opiate dependence. The withdrawal-suppressing effects of $\mathrm{HBO}_{2}$ are clear from our results, but its mechanism of action is less clear.

Other studies have been able to precipitate withdrawal in morphine-dependent mice with much lower doses of naloxone [Ho et al., 1972; Friedler et al., 1972]. One reason for selection of $5.0 \mathrm{mg} / \mathrm{kg}$ of naloxone as our dose for precipitating withdrawal was a previous finding from our laboratory that $\mathrm{HBO}_{2}$-induced antinociception in rodents was sensitive to antagonism by both opioid antagonist drugs as well as rabbit antisera against selected endogenous opioid peptides, namely dynorphin [Zelinski et al., 2009; Heeman et al., 2013; Gibbons et al., 2013]. This suggests that a mechanism of $\mathrm{HBO}_{2}$-induced antinociception is stimulation of neuronal release of opioid peptides. Since increased opioid peptides are a possible mechanism for relief of opiate withdrawal [Dzoljic et al., 1986; Maldonado et al., 1989], the higher dose of naloxone was selected to determine whether greater opioid receptor blockade might interfere with the ability of $\mathrm{HBO}_{2}$ to ameliorate withdrawal signs.

There is also evidence that $\mathrm{HBO}_{2}$ treatment increases levels of nitric oxide (NO) oxidation products in the rat brain [Ohgami et al., 2008], increases expression of constitutive nitric oxide synthase (NOS) [Lin et al., 2011], and stimulates synthesis of NO in brain tissue [Thom et al., 2003]. Our own studies have consistently demonstrated that inhibition of brain NOS antagonizes $\mathrm{HBO}_{2}$-induced antinociception [Ohgami et al., 2009; Zelinski et al., 2009; Chung et al., 2010]. These findings suggest that $\mathrm{HBO}_{2}$ increases NOS activity. If an increase in $\mathrm{NO}$ activity is involved in suppression of opiate withdrawal by $\mathrm{HBO}_{2}$, it runs contrary to evidence that increased NOS activity is involved in the expression of opiate withdrawal itself [Machelska et al.,1997; Kumar and Bhargava, 1997; Cuéllar et al., 2000]. This is evidenced by suppression of the opiate withdrawal syndrome by NOS inhibitors [London et al., 1995; Bhargava, 1995; Leza et al., 1996; Dambisya and Lee, 1996]. This discrepancy may represent a delicate balance in the influence of $\mathrm{NO}$ on expression of opioid withdrawal not unlike the reported pronociceptive vs. antinociceptive roles of NO [Schmidtko et al., 2009; Schmidtko, 2015], anxiogenic vs. anxiolytic functions of NO [Volke et al., 1997; Vale et al., 1998] as well as its involvement in neurotoxicity vs. neuroprotection [Calabrese et al., 2007]. Although further research is needed to elucidate the mechanism of action of $\mathrm{HBO}_{2}$, this study provides grounds for optimism in the search for effective alternative treatments for opiate withdrawal.

\section{Experimental procedures}

\subsection{Animals}

Male NIH Swiss mice, 20-26 g, were purchased from Harlan Laboratories (Indianapolis, Indiana) for this research. All experiments were approved by the Washington State University Institutional Animal Care and Use Committee subject to post-approval review. Research was conducted in accordance in accordance with The Guide for the Care and Use of Laboratory Animals, $8^{\text {th }}$ Edition (National Academies Press, Washington, DC, 2010). 
Mice were housed four per cage in the Wegner Hall Vivarium at Washington State University with access to food and water ad libitum. The facility, which is accredited by the Association for Assessment and Accreditation of Laboratory Animal Care (AAALAC), was maintained on a 12-h light:dark cycle (lights on 07:00-19:00 h) under standard conditions $\left(22 \pm 1{ }^{\circ} \mathrm{C}\right.$ room temperature, $33 \%$ humidity). Mice were kept in the holding room for at least four days after arrival in the facility for acclimation prior to use.

\subsection{Treatment with $\mathrm{HBO}_{2}$}

Mice were placed in a B-11 research hyperbaric chamber (Reimers Systems, Inc., Lorton, VA). The chamber was ventilated with $100 \% \mathrm{O}_{2}$, U.S.P. (A-L Compressed Gases Inc., Spokane, WA) at a flow rate of $20 \mathrm{~L} / \mathrm{min}$ to minimize accumulation of nitrogen and carbon dioxide. The pressure within the cylindrical clear acrylic chamber $(27.9 \mathrm{~cm}$ diameter $\times 55.9$ $\mathrm{cm} \mathrm{L}$ ) was increased from 1.0 to 3.5 ATA over a period of $2 \mathrm{~min}$. Animals breathed spontaneously during the $\mathrm{HBO}_{2}$ treatment. After conclusion of the $\mathrm{HBO}_{2}$ treatment, mice were then decompressed over 2-3 min. Different groups of mice were treated for 30 or 60 min with $\mathrm{HBO}_{2}$ at 3.5 atmospheres absolute (ATA). Control mice were placed in the open hyperbaric chamber and allowed to breathe room air.

\subsection{Drugs}

The following drugs were used in this research: morphine sulfate, U.S.P. (West-Ward, Eatontown, NJ); and naloxone hydrochloride (Tocris Bioscience, Minneapolis, MN). Both drugs were freshly prepared in $0.9 \%$ physiological saline.

For induction of physical dependence, morphine sulfate was administered s.c. twice daily at 0830 and $1630 \mathrm{~h}$ for four consecutive days (Fig. 1). The daily dose of morphine sulfate was $50 \mathrm{mg} / \mathrm{kg}$ on day $1,75 \mathrm{mg} / \mathrm{kg}$ on day $2,100 \mathrm{mg} / \mathrm{kg}$ on day 3 and $125 \mathrm{mg} / \mathrm{kg}$ on day 4 . To precipitate opiate withdrawal, $5.0 \mathrm{mg} / \mathrm{kg}$ naloxone was administered i.p. on day 5 . The dose schedule was derived from the scientific literature [Seyedi et al., 2014], but the t.i.d. schedule for three days was lengthened to b.i.d. for four days.

\subsection{Assessment of withdrawal symptoms}

Immediately following the naloxone injection, mice were placed in a Plexiglas ${ }^{\circledR}$ test chamber $(40 \mathrm{~cm} \mathrm{~L} \times 20 \mathrm{~cm} \mathrm{~W} \times 25 \mathrm{~cm} \mathrm{H})$ in groups of four and video-recorded for $30 \mathrm{~min}$. The frequency of distinct physical signs of withdrawal—jumping, forepaw tremor, and wetdog shakes (whole-body shakes), rearing and defecation — were determined for each mouse. Vehicle-treated mice served as control. Multiple raters were used for some but not all experiments; at least one of the raters was blinded to the drug treatment.

\subsection{Statistical analysis of data}

Inter-rater reliability was estimated using intraclass correlation coefficients (ICCs) (SPSS v. 23.0, SPSS Inc., Chicago, IL). Following determination of reliability between raters, each individual endpoint was investigated for outliers using Grubb's maximum normed residual test. Outliers identified by the Grubb's test caused all endpoint data from that animal to be removed from further analysis. Grubb's test identified outliers only in the jumping and wet dog shake endpoints. A one-way between groups analysis of variance (ANOVA) was run 
along with Levene's test for homogeneity of variance. Where a violation of Levene's test was found, we used Welch's F test to analyze the differences in frequency of withdrawal signs between groups with unequal variances [Welch, 1951]. A Dunnett's post hoc test was applied to identify statistically significant differences between groups

\section{Conclusion}

A 30- or 60-min treatment with $\mathrm{HBO}_{2}$ can suppress multiple naloxone-precipitated physical signs of withdrawal in morphine-dependent mice. These results support an earlier report that $\mathrm{HBO}_{2}$ therapy can be beneficial in treatment of heroin addicts.

\section{Acknowledgments}

This research was supported in part by NIH Grant AT-007222 (RMQ), an Undergraduate Research Fellowship from the Washington State University Alcohol and Drug Abuse Research Program (DN), and funds from the Honors College Distinguished Professorship at Washington State University (RMQ) and the Chico Hyperbaric Center (Chico, CA).

\section{References}

Bhargava HN. Attenuation of tolerance to, and physical dependence on, morphine in the rat by inhibition of nitric oxide synthase. Gen. Pharmacol. 1995; 26:1049-1053. [PubMed: 7557249]

Calabrese V, Mancuso C, Calvani M, Rizzarelli E, Butterfield DA, Stella AM. Nitric oxide in the central nervous system: neuroprotection versus neurotoxicity. Nat. Rev. Neurosci. 2007; 8:766-775. [PubMed: 17882254]

Chung E, Zelinski LM, Ohgami Y, Shirachi DY, Quock RM. Hyperbaric oxygen treatment induces a 2phase antinociceptive response of unusually long duration in mice. J. Pain. 2010; 11:847-853. [PubMed: 20418186]

Cuéllar B, Fernández AP, Lizasoain I, Moro MA, Lorenzo P, Bentura ML, Rodrigo J, Leza JC. Upregulation of neuronal NO synthase immunoreactivity in opiate dependence and withdrawal. Psychopharmacology (Berl). 2000; 148:66-73. [PubMed: 10663419]

Dambisya YM, Lee TL. Role of nitric oxide in the induction and expression of morphine tolerance and dependence in mice. Br. J. Pharmacol. 1996; 117:914-918. [PubMed: 8851510]

Dzoljic MR, Rademaker B, vd Poel-Heisterkamp AL, Ukponmwan OE, Haffmans J. Enkephalinase inhibition suppresses naloxone-induced jumping in morphine-dependent mice. Arch. Int. Pharmacodyn. Ther. 1986; 283:222-228. [PubMed: 3539055]

Epifanova NM. Hyperbaric oxygenation in the treatment of patients with drug addiction, narcotic addiction and alcoholism in the post-intoxication and abstinence periods [Russian]. Anesteziol. Reanimatol. 1995; 3:34-39. [PubMed: 7653862]

Friedler G, Bhargava HN, Quock R, Way EL. The effect of 6-hydroxydopamine on morphine tolerance and physical dependence. J. Pharmacol. Exp. Ther. 1972; 183:49-55. [PubMed: 4673087]

Gabra BH, Bailey CP, Kelly E, Smith FL, Henderson G, Dewey WL. Pre-treatment with a PKC or PKA inhibitor prevents the development of morphine tolerance but not physical dependence in mice. Brain Res. 2008; 1217:70-77. [PubMed: 18501877]

Gibbons CR, Liu S, Zhang Y, Sayre CL, Levitch BR, Moehlmann SB, Shirachi DY, Quock RM. Involvement of brain opioid receptors in the antiallodynic effect of hyperbaric oxygen $\left(\mathrm{HBO}_{2}\right)$ in rats with sciatic nerve crush-induced neuropathic pain. Brain Res. 2013; 1537:111-116. [PubMed: 23998986]

Heeman JH, Zhang Y, Shirachi DY, Quock RM. Involvement of spinal cord opioid mechanisms in the acute antinociceptive effect of hyperbaric oxygen in mice. Brain Res. 2013; 1540:42-47.

[PubMed: 24113418] 
Ho IK, Lu SE, Stolman S, Loh HH, Way EL. Influence of p-chlorophenylalanine on morphine tolerance and physical dependence and regional brain serotonin turnover studies in morphine tolerant-dependent mice. J. Pharmacol. Exp. Ther. 1972; 182:1655-156.

Kleber HD. Pharmacologic treatments for opioid dependence: detoxification and maintenance options. Dialogues Clin. Neurosci. 2007; 9:455-470. [PubMed: 18286804]

Kumar S, Bhargava HN. Time course of the changes in central nitric oxide synthase activity following chronic treatment with morphine in the mouse: reversal by naltrexone. Gen. Pharmacol. 1997; 29:223-227. [PubMed: 9251903]

Leza JC, Lizasoain I, Cuéllar B, Moro MA, Lorenzo P. Correlations between brain nitric oxide synthase activity and opiate withdrawal. Naunyn Schmiedebergs Arch. Pharmacol. 1996; 353:349_ 354. [PubMed: 8692292]

Lin CD, Wei IH, Lai CH, Hsia TC, Kao MC, Tsai MH, Wu CH, Tsai MH. Hyperbaric oxygen upregulates cochlear constitutive nitric oxide synthase. BMC Neurosci. 2011; 12:21. [PubMed: 21342510]

London ED, Kimes AS, Vaupel DB. Inhibitors of nitric oxide synthase and the opioid withdrawal syndrome. NIDA Res. Monogr. 1995; 147:170-181. [PubMed: 8742786]

Machelska H, Ziólkowska B, Mika J, Przewłocka B, Przewłocki R. Chronic morphine increases biosynthesis of nitric oxide synthase in the rat spinal cord. NeuroReport. 1997; 8:2743-2747. [PubMed: 9295111]

Maldonado R, Daugé V, Callebert J, Villette JM, Fournié-Zaluski MC, Feger J, Roques BP. Comparison of selective and complete inhibitors of enkephalin-degrading enzymes on morphine withdrawal syndrome. Eur. J. Pharmacol. 1989; 165:199-207. [PubMed: 2776828]

Ohgami Y, Chung E, Shirachi DY, Quock RM. The effect of hyperbaric oxygen on regional brain and spinal cord levels of nitric oxide metabolites in rat. Brain Res. Bull. 2008; 75:668-673. [PubMed: 18355644]

Ohgami Y, Zylstra CC, Quock LP, Chung E, Shirachi DY, Quock RM. Nitric oxide in hyperbaric oxygen-induced acute antinociception in mice. NeuroReport. 2009; 20:1325-1329. [PubMed: 19730405]

Seyedi SY, Salehi F, Payandemehr B, Hossein S, Hosseini-Zare MS, Nassireslami E, Yazdi BB, Sharifzadeh M. Dual effect of cAMP agonist on ameliorative function of PKA inhibitor in morphine-dependent mice. Fundam. Clin. Pharmacol. 2014; 28:445-454. [PubMed: 24033391]

Schmidtko A. Nitric oxide-mediated pain processing in the spinal cord. Handb. Exp. Pharmacol. 2015; 227:103-117. [PubMed: 25846616]

Schmidtko A, Tegeder I, Geisslinger G. No NO, no pain?. The role of nitric oxide and cGMP in spinal pain processing. Trends Neurosci. 2009; 32:339-346. [PubMed: 19414201]

Thom SR, Buerk DG. Nitric oxide synthesis in brain is stimulated by oxygen. Adv. Exp. Med. Biol. 2003; 510:133-137. [PubMed: 12580417]

Vale AL, Green S, Montgomery AM, Shafi S. The nitric oxide synthesis inhibitor L-NAME produces anxiogenic-like effects in the rat elevated plus-maze test, but not in the social interaction test. J. Psychopharmacol. 1998; 12:268-272. [PubMed: 10958253]

Volke V, Soosaar A, Kõks S, Bourin M, Männistö PT, Vasar E. 7-Nitroindazole, a nitric oxide synthase inhibitor, has anxiolytic-like properties in exploratory models of anxiety. Psychopharmacology. 1997; 131:399-405. [PubMed: 9226743]

Weaver, L. Hyperbaric Oxygen Therapy Indications. 13th. North Palm Beach: Best Publishing Company; 2014.

Welch BL. On the comparison of several mean values: an alternative approach. Biometrika. 1951; 38:330-336.

Wu P, Shi HS, Luo YX, Zhang RX, Li JL, Shi J, Lu L, Zhu WL. Neuropeptide trefoil factor 3 attenuates naloxone-precipitated withdrawal in morphine-dependent mice. Psychopharmacology (Berl.). 2014; 231:4659-4668. [PubMed: 24825609]

Zelinski LM, Ohgami Y, Chung E, Shirachi DY, Quock RM. A prolonged NO-dependent, opioidmediated antinociceptive effect of hyperbaric oxygen in mice. J. Pain. 2009; 10:167-172. [PubMed: 18976963] 


\section{Highlights}

- $\quad$ Physical dependence was induced by twice-daily morphine injections over 4 days.

- $\quad$ Naloxone precipitated jumping, tremors, wet-dog shakes, rearing and defecation.

- Withdrawal signs were suppressed by treatment with hyperbaric oxygen $\left(\mathrm{HBO}_{2}\right)$. 


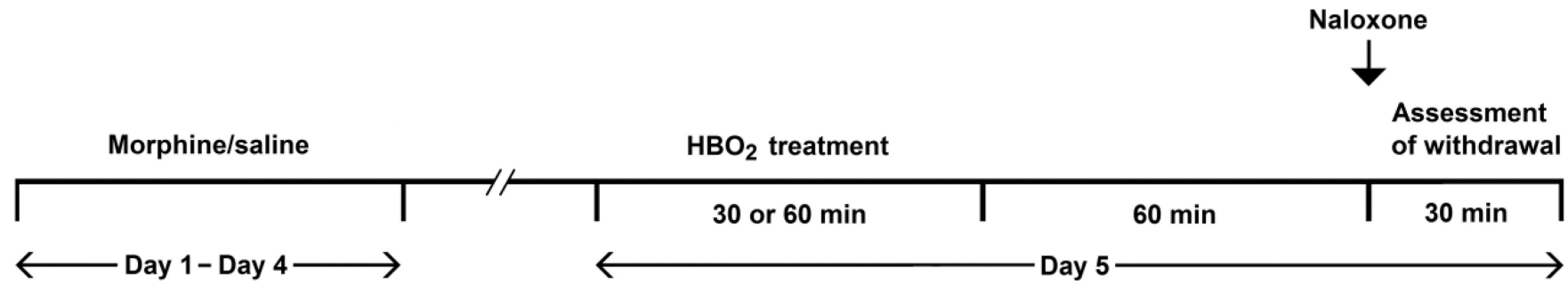

Fig. 1.

Timeline of research. Mice received s.c. injections of morphine sulfate or saline b.i.d. for four consecutive days. On day 5, all mice received $\mathrm{HBO}_{2}$ or room air treatment for 30 or 60 min. One hour later, mice received an i.p. injection of naloxone to precipitate withdrawal symptoms or saline as control. Recording of withdrawal symptoms started immediately after the naloxone injection, and lasted for $30 \mathrm{~min}$. 


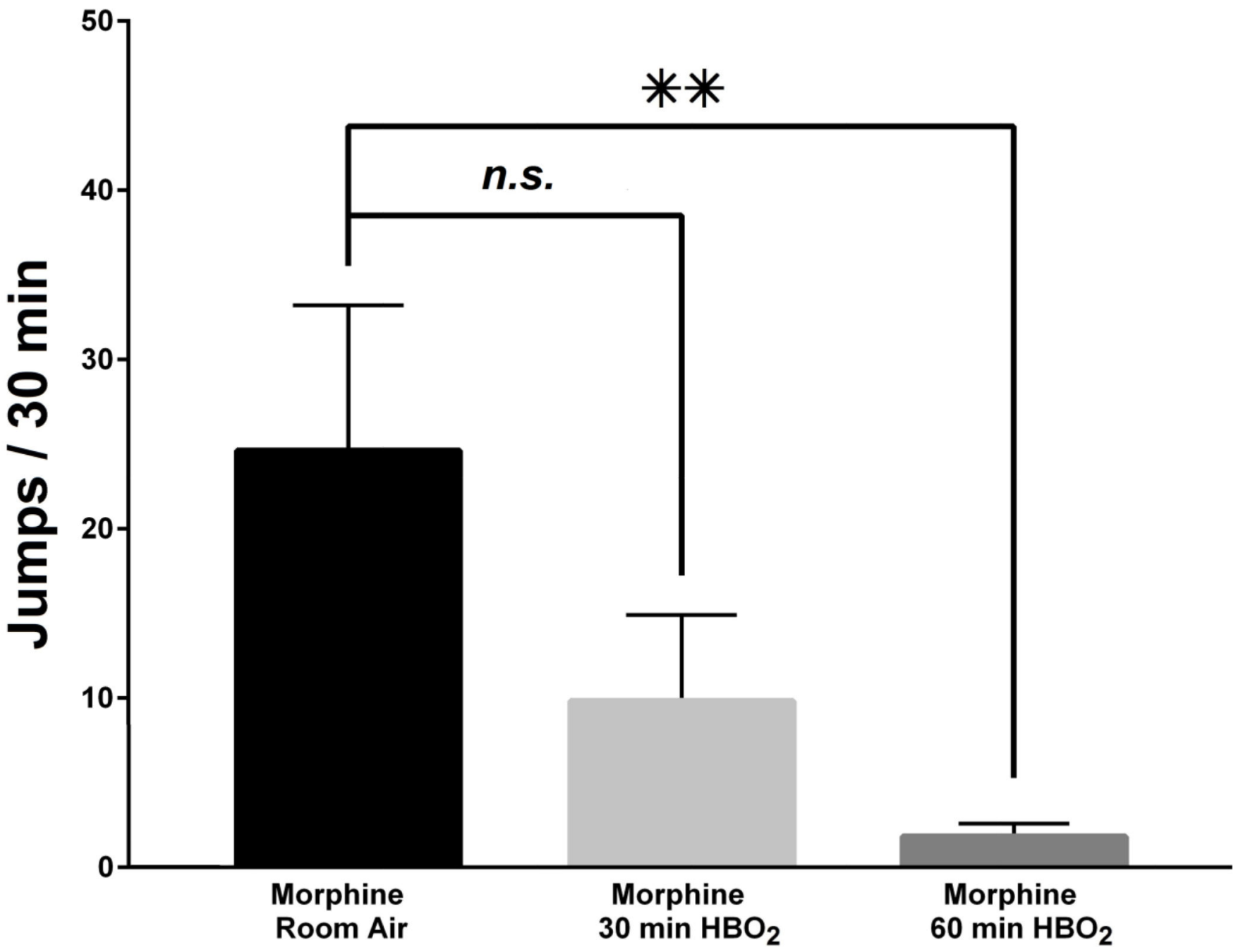

Fig. 2.

Effect of $\mathrm{HBO}_{2}$ on naloxone-induced jumping in chronic morphine-treated mice. Data are presented as the mean \pm SEM (Morphine + Room Air, $\mathrm{N}=14$; Morphine $+30-$ min $\mathrm{HBO}_{2}, \mathrm{~N}$ = 14; and Morphine +60 -min $\mathrm{HBO}_{2}, \mathrm{~N}=21$ ). Significance of difference: $* *, P<0.01$, compared to Morphine + Room Air control group. 


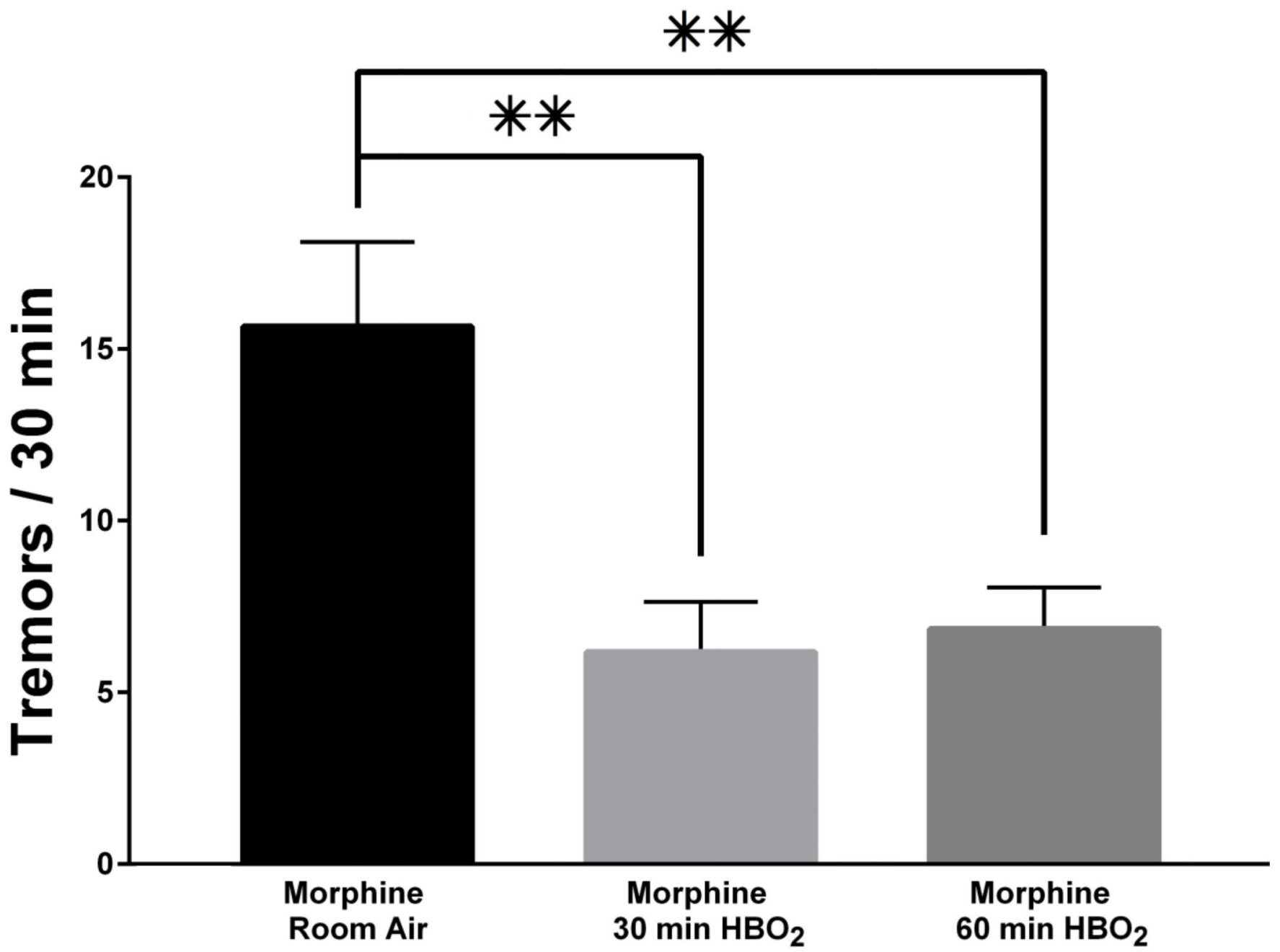

Fig. 3.

Effect of $\mathrm{HBO}_{2}$ on naloxone-induced tremor in chronic morphine-treated mice. Data are presented as the mean \pm SEM (Morphine + Room Air, $\mathrm{N}=18$; Morphine $+30-\min \mathrm{HBO}_{2}, \mathrm{~N}$ = 14; and Morphine +60 -min $\mathrm{HBO}_{2}, \mathrm{~N}=21$ ). Significance of difference: $* *, P<0.01$, compared to Morphine + Room Air control group. 


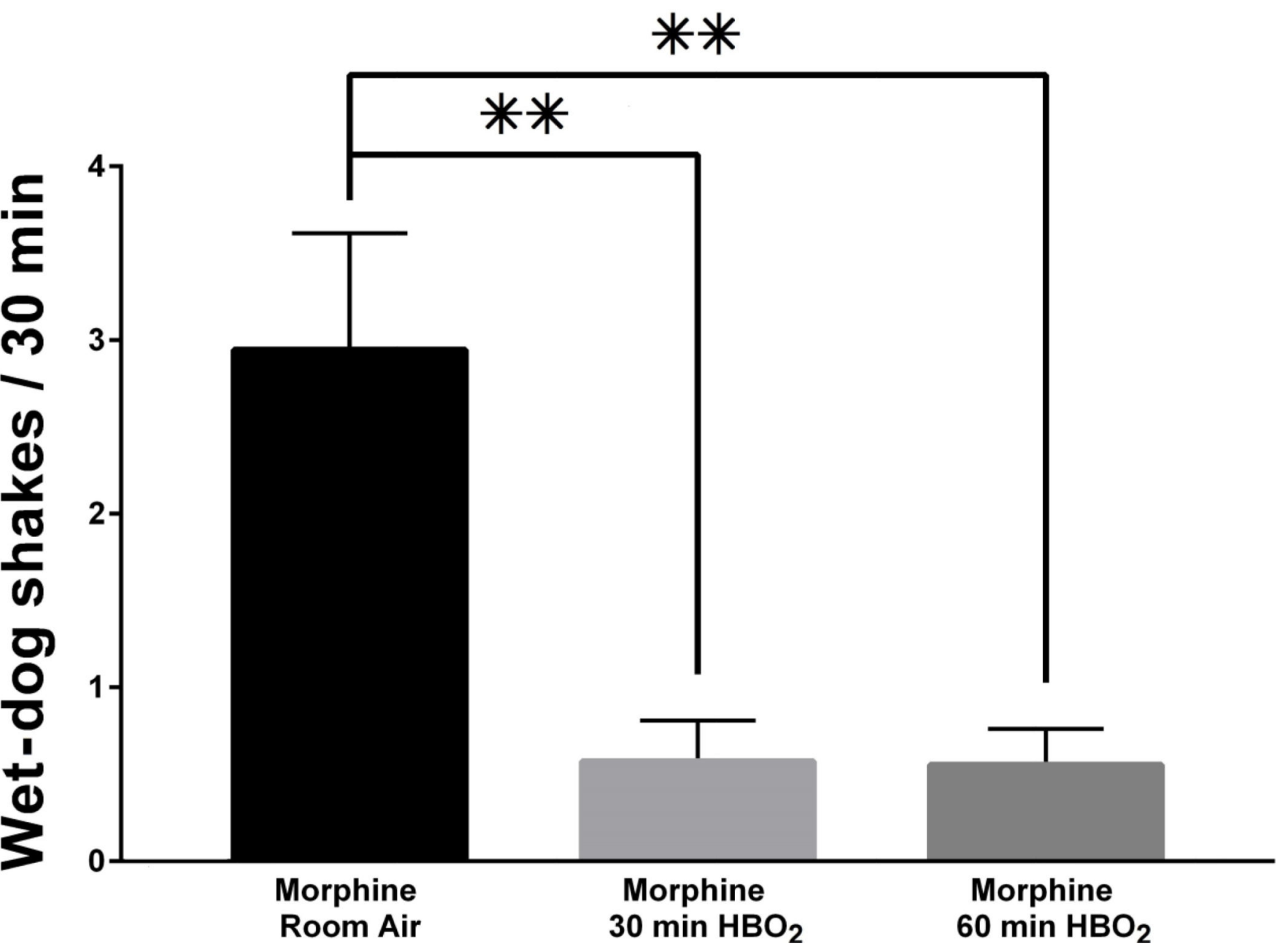

Fig. 4.

Effect of $\mathrm{HBO}_{2}$ on naloxone-induced wet-dog shakes in chronic morphine-treated mice.

Data are presented as the mean \pm SEM (Morphine + Room Air, N = 18; Morphine + 30-min $\mathrm{HBO}_{2}, \mathrm{~N}=14$; and Morphine $+60-\min \mathrm{HBO}_{2}, \mathrm{~N}=21$ ). Significance of difference: $* *, P<$ 0.01, compared to Morphine + Room Air control group. 


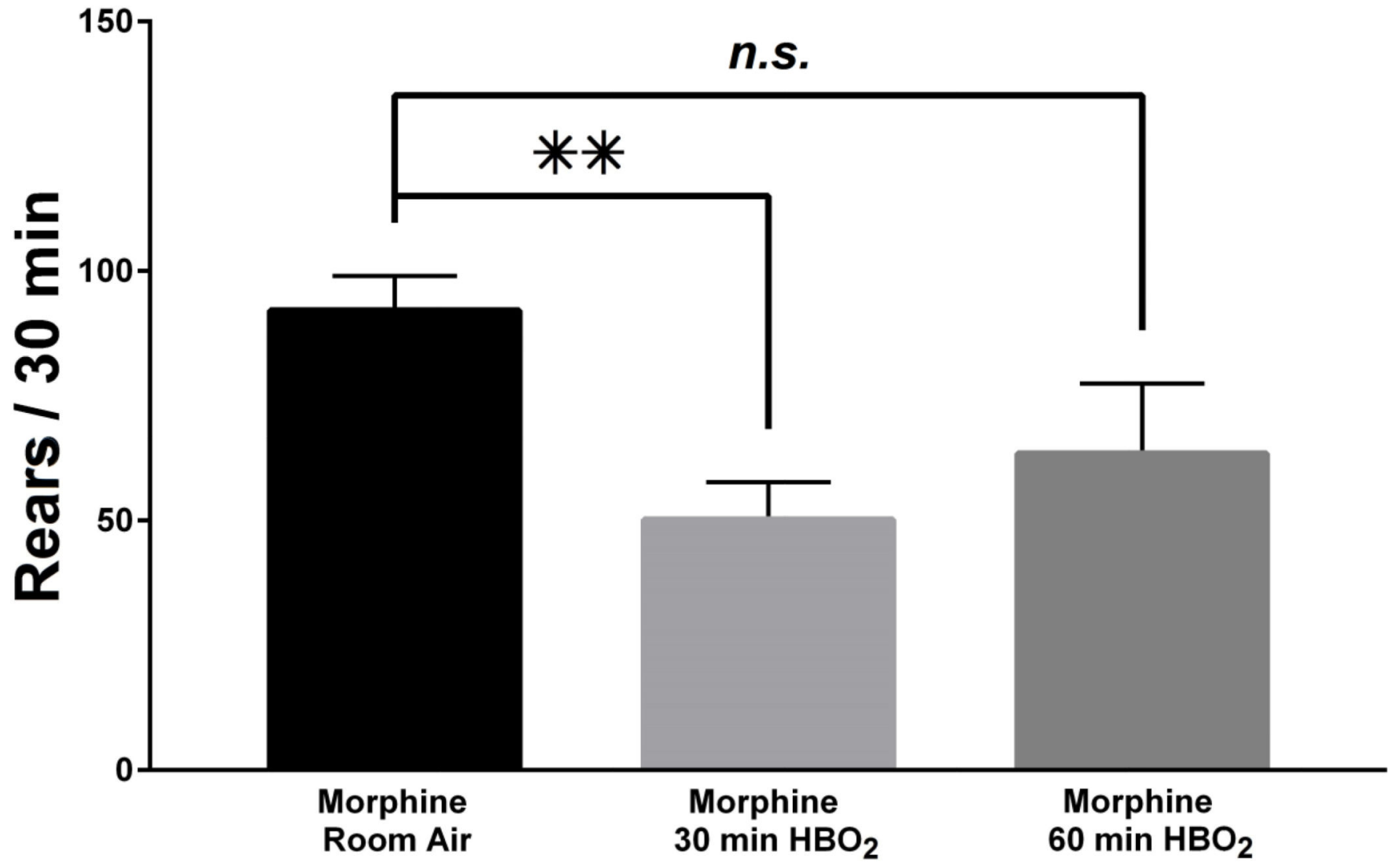

Fig. 5.

Effect of $\mathrm{HBO}_{2}$ on naloxone-induced rearing in chronic morphine-treated mice. Data are presented as the mean \pm SEM (Morphine + Room Air, $\mathrm{N}=14$; Morphine $+30-\min \mathrm{HBO}_{2}, \mathrm{~N}$ $=10$; and Morphine $+60-\min \mathrm{HBO}_{2}, \mathrm{~N}=12$ ). Significance of difference: $* *, P<0.01$, compared to Morphine + Room Air control group. 


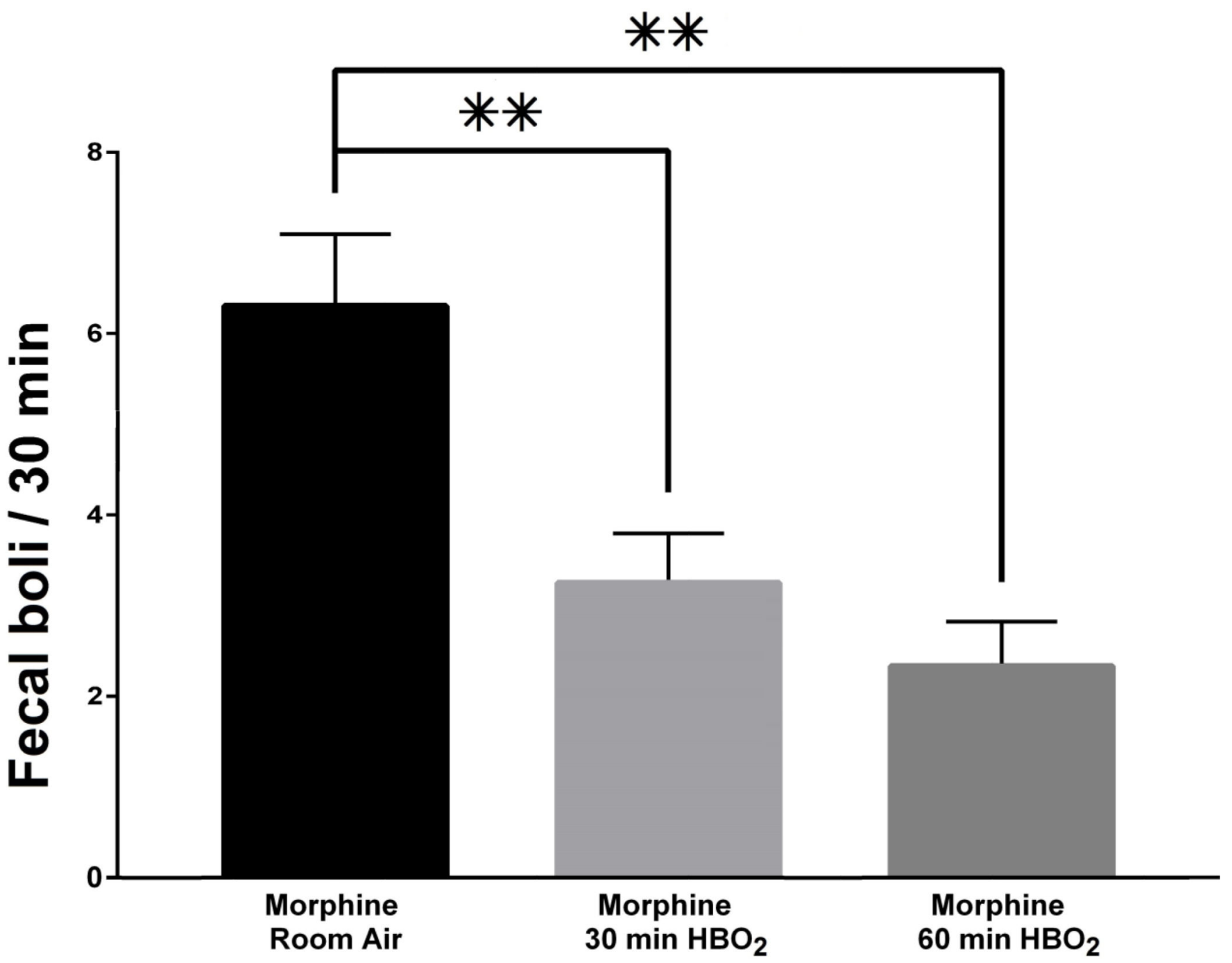

Fig. 6.

Effect of $\mathrm{HBO}_{2}$ on naloxone-induced defecation in chronic morphine-treated mice. Data are presented as the mean \pm SEM (Morphine + Room Air, $\mathrm{N}=14$; Morphine +30 -min $\mathrm{HBO}_{2}, \mathrm{~N}$ $=10$; and Morphine $+60-\min \mathrm{HBO}_{2}, \mathrm{~N}=12$ ). Significance of difference: **, $P<0.01$, compared to Morphine + Room Air control group. 